УДК 636.4:591.18

(C) 2013

Замазій А. А., доктор ветеринарних наук

Полтавська державна аграрна академія

Камбур М. Д., доктор ветеринарних наук, професор, Піхтірьова А. В., аспірант *

Сумський національний аграрний університет

\title{
УДОСКОНАЛЕННЯ МЕТОДИКИ ВИЗНАЧЕННЯ ТИПІВ ВИЩОЇ НЕРВОВОЇ ДІЯЛЬНОСТІ У СВИНЕЙ
}

\section{Рецензент - доктор ветеринарних наук М. В. Скрипка}

Наведені дані з удосконалення методики визначення типів вищої нервової діяльності у свиноматок. За даною методикою можна провести визначення типологічних характеристик нервової системи свиноматок у виробничих умовах, звичних для тварин (безпосередньо у свинарнику). Це не потребує облаштування манежу (майданчика) та використання спеціального обладнання, не стресує й не травмує свиноматок. Сутність запропонованої нами методики полягає у виробленні окремих рухово-харчових реакцій, щчо визначають властивості нервової системи кожної тварини окремо.

Ключові слова: свиноматки, методика, тип вищої нервової діяльності (ВНД).

Постановка проблеми. Загальновідомо, що актуальним питанням сьогодення залишається забезпечення населення Землі продуктами харчування, зокрема тваринного походження, високої якості та в достатній кількості. Однією з головних умов для вирішення такого завдання $\epsilon$ використання закономірностей життєвих проявів сільскогосподарських тварин із метою створення оптимальних умов їх утримання $[1,8]$.

Основне завдання працівників тваринництва підвищення продуктивності та життєздатності тварин. Організувати раціональне утримання сільскогосподарських тварин, їх планомірне розведення, отримати максимальну продуктивність можливо за умови успішного й широкого використання фізіологічного вчення І.П. Павлова про вищу нервову діяльність [1-3].

Нами були проведені дослідження з удосконалення методики визначення типологічних особливостей нервової системи свиней.

Проведені дослідження були складовою частиною тематичного плану кафедри анатомії, нормальної та патологічної фізіології, розділ 2 «Фізіолого-біохімічні параметри пре- та постнатального розвитку тварин та їх корекція» (20062014 pp.), номер державної реєстрації $0108 \mathrm{U} 010281$.

Аналіз основних досліджень і публікацій, у яких започатковано розв'язання проблеми. Різке збільшення концентрації тварин на обмеженій площі, яке виникає в сучасних умовах інтенсивного промислового тваринництва, потребує визначення фізіологічних особливостей кожного організму окремо для створення оптимально-комфортних умов утримання [4].

Поведінка тварин є важливим фактором, знання якого дає можливість раціонально займатися розвитком тваринництва. Вчення І. П. Павлова про вищу нервову діяльність, що відкрило основні закономірності, яким підлягає діяльність організму тварини, мало виняткове значення у вивченні поведінки тварин $[1,2]$.

У наш час питання зв'язку типів вищої нервової діяльності з поведінкою тварин вивчене недостатньо й залишається досить важливим. Встановлений певний зв'язок продуктивності сільськогосподарських тварин із типологічними особливостями їх вищої нервової діяльності. Нині відома залежність функції молоковіддачі, лактаційної домінанти, складу молока, конституції корів залежно від типу вищої нервової діяльності $[3,8]$. У коней встановлений зв'язок типів ВНД із працездатністю [6]. Стосовно зв'язку типу нервової діяльності свиней з їх господарсько корисними ознаками існує небагато робіт [5] та й методи $€$ досить складними для застосування у виробничих умовах.

Тому метою наших досліджень було удосконалення методики визначення типів вищої нервової діяльності свиней.

* Науковий керівник - доктор ветеринарних наук, професор М. Д. Камбур 
Завдання: провести визначення типологічних характеристик нервової системи свиноматок у виробничих умовах, звичних для тварин (безпосередньо у свинарнику); виробити окремі рухово-харчові реакції, що визначають властивості нервової системи кожної тварини окремо.

Матеріали і методи досліджень. Дослідження типів вищої нервової діяльності свиней проводились у виробничих умовах господарства ТОВ «Рябушківський бекон» на свиноматках породи велика біла + ландрас. Із цією метою були підібрані тварини-аналоги 2-3-го опоросів.

Удосконалена нами методика визначення типів ВНД у свиноматок відрізняється від методики, запропонованої В. В. Науменком, тим, що не потребує облаштування манежу та використання специфічного обладнання для проведення дослідів. Дана методика не стресує тварин, запобігає травматизації, є більш природньою, поскільки експериментальна частина проводиться безпосередньо у свинарнику в умах, звичних для свиноматок.

Сутність рухово-харчової методики полягає у виробленні окремих рухових реакцій, які визначають властивості нервової системи кожної тварини зокрема. Щоб виявити тип вищої нервової діяльності свиноматки, необхідно визначити силу, врівноваженість та рухливість нервових процесів.

Реакції тварин на подразник виражаються у балах (б.), від одного до трьох. На підставі одержаних результатів тварин розділяють на чотири групи (за типами вищої нервової діяльності).

Для удосконалення методики визначення типів ВНД у свиноматок використовували одну частину свинарника, а саме коридор, який з’єднує вхідні двері з вигульного майданчика та станок, де утримуються тварини. Відстань від вхідних дверей до годівниці, що знаходиться в станку, становить 10 метрів.

Удосконалений нами метод визначення типологічних особливостей вищої нервової діяльності свиней в умовах виробництва включає в себе тести, які дають змогу визначити типи вищої нервової діяльності свиноматок.

Результати досліджень. За результатами проведених досліджень тварин можна поділити на чотири групи за основними типологічними характеристиками вищої нервової діяльності.

Для свиноматок із сильними врівноваженими рухливими нервовими процесами характерними були наступні показники: орієнтувальна реакція швидка й спокійна; умовний рефлекс на місце підкормки утворюється швидко (1-3 рази), до годівниці підходять зазвичай спокійно; лінія підходу до годівниці пряма; спокійно поїдає корм із годівниці з першого або другого підходу; при першій обробці спокійно й швидко переходить від порожньої годівниці до іншої, з кормом; диференціювання місця пустої годівниці та 3 кормом відбувається швидко (1-2 підходи) й залишається стійкою; реакція на звуковий та зоровий подразники незначна, спокійна, орієнтувальна; у деяких тварин реакція спочатку бурхлива, але швидко згасає, їдять весь час; тварина може зробити зворотну переробку протягом одного дослідного дня; залишається спокійною за будь-яких умов, на все спокійно та швидко реагує.

Для свиноматок із сильними врівноваженими інертними нервовими процесами характерним було наступне: орієнтувальна реакція спокійна; до місця підкормки підходить спокійно за другим-четвертим разом; при переробці не в усіх тварин лінія підходу до годівниці з кормом пряма; корм поїдає спокійно з першого або другого підходу; при першій переробці свиноматка залишається спокійною, хоча може не відразу перейти від однієї годівниці до іншої, - іноді необхідно показувати підкормку; диференціювання місця порожньої годівниці та 3 кормом відбувається дещо повільніше, ніж у тварин із рухливими нервовими процесами (2-4 підходи) і менш стійка; реакція на звуковий та зоровий подразники незначна, спокійна, малопомітна; у деяких тварин реакція спочатку буває достатньо сильною, проте швидко згасає, їдять весь час; робить одну переробку протягом одного дослідного дня; тварина залишається спокійною за будь-яких обставин.

Свиноматки 3 сильними неврівноваженими нервовими процесами мали наступні показники: зовнішнє гальмування не відмічається; орієнтувальна реакція зазвичай швидка, але не завжди чітко проявляється через надмірне збудження; до годівниці підходить (зазвичай біжить) самостійно за другим-четвертим разом; лінія підходу до годівниці при переробці невизначена: досить рідко - пряма, часто заходять до порожньої годівниці, іноді колами; в однієї й тієї ж свиноматки змінюється від досліду до досліду; починає їсти підкормку з першого-третього підходу, але їсть погано, неспокійно, штовхає та гризе годівницю; при першій переробці переходить до іншої годівниці, але біля порожньої годівниці деякі тварини бувають збудженими, штовхають годівницю, гризуть іi; диференціювання місця порожньої годівниці та 3 кормом відбувається по-різному, але зазвичай у третим-сьомим підхідом і в подальшому нестійка; на звуковий та зоровий подразники реакція 
сильна (свиня сахається), довго не згасає, іноді спостерігається реакція агресії, але їсти не перестає; зазвичай робить одну переробку протягом одного дослідного дня, іноді жодної; не тільки за нових умов, але й у звичній обстановці свині збуджені, непокояться у станках.

Для свиноматок зі слабкими нервовими процесами характерним було наступне: при вході в приміщення (свинарник) орієнтувальна реакція дещо пригнічена: свиня зупиняється або йде досить повільно (необхідно підганяти), із зупинками; деякі тварини поводяться збуджено, хрокають, вищать; підходить до годівниці повільно за третім-сьомим разом; лінія підходу досить рідко пряма, зазвичай із підходом до порожньої годівниці, колами; починає їсти з годівниці з другогоп'ятого підходів, їсть погано, непокоїться; спокійно стояти не може, хрокає, штовхає й гризе годівницю; деякі свині «застигають» на місці; при першій переробці зупиняється біля порожньої годівниці (1 хвилина й більше), відходить назад; необхідно підганяти до годівниці 3 під-

\section{БІБЛІОГРАФІЯ}

1. Батуев А. С. Высшая нервная деятельность / Батуев А. С. - М. : Высшая школа, 1991. - 256 с. 2. Данилова H. Н. Физиология высшей нервной деятельности / Н. Н. Данилова, А. Л. Крылова. М. : Учебная литература, 1997. - 432 с.

3. Закс М. Г. Молочная железа. Нервная и гуморальная регуляция её развития и функции / Закс М. Г. - Л. : Наука, 1964. - 286 с.

4. Ладан П. Е. Свиноводство / Ладан П. Е. - М. : Колос, 1978. - $304 \mathrm{c}$.

5. Науменко В. В. Некоторые особенности высшей нервной деятельности и типы нервной сис- кормкою; диференціювання порожньої годівниці та 3 кормом утворюється вкрай повільно - вона зазвичай нестійка; реакція на звуковий та зоровий подразники сильна й посилюється за повторних подразнень, свиня зазвичай перестає їсти і відходить від годівниці; реакція повністю не згасає, іноді лише послаблюється; переробку може не зробити взагалі або робить один раз, однак дуже важко; загальна поведінка різна: іноді свиня малорухлива, флегматична, а іноді, навпаки, жвава й рухлива.

Висновки. Запропонований нами метод визначення типологічних особливостей вищої нервової діяльності свиней відрізняється від інших методів тим, що дає змогу провести дослідження (тести) з визначення типу вищої нервової діяльності тварин у виробничих умовах господарства та виключає необхідність створення майданчика й використання приладів і обладнання.

Дослідження, проведені в цьому напрямі, дадуть можливість визначити тварин із найбільш цінними продуктивними якостями.

темы у свиней: автореф. дис. на соискание ученой степени докт. биол. наук: спец. 802 «Ветеринарная физиология» / В. В. Науменко. - Львов, 1968. $-36 \mathrm{c}$.

6. Ползунова A. М. Определение типа высшей нервной деятельности лошади //Альфа кентавра / А. М. Ползунова, И. Шрейнер. - 2007.

7. Федий Е. М. Физиология сельскохозяйственных животных / Е. М. Федий, В. В. Науменко. К. : Вища школа, 1978. -416 с.

8. Цахаев Г. А. Нервная регуляция секркции молока / Цахаев Г. А. - Л. : Наука, 1974. - 187 с. 